\title{
In Search of a Unit of Speech. Methodological Reflections Sparked by a New Understanding of Language
}

\section{Jolanta Antas}

Jagiellonian University, Poland jolanta.antas@uj.edu.pll

\section{Malgorzata Majewska}

Jagiellonian University, Poland gomajewska@gmail.com

\begin{abstract}
The article aims at a revision of such terms as sentence, utterance, speech act, or communication event in view of new research needs and a broader understanding of language as involved in a complex communication process and, thus, considered a tool for not only generating meanings but also conveying them in interpersonal collaboration. From such a perspective, language appears to be not only a system but also one of the tools of symbolising meanings and intentional acts which serve the purpose of generating and regulating social bonds. The purpose of the authors is, thus, to define traditional linguistic concepts in order to make them good tools to describe the types of communication events and the ensuing individual interactions. We also intend to resolve the existing terminological confusion, i.e. to eliminate the employment of the same terms to describe different speech events and different levels of speech, and, as a result, to place the concepts in a hierarchy and assign them clear definitions. All this is undertaken in order to fit in the perspective of the observer as an active participant and contributor to the communication event, utterance or even a sentence.
\end{abstract}

Keywords: utterance, sentence, unit of speech, communication event, speech event, speech act

\section{Streszczenie}

W poszukiwaniu jednostki mowy. Metodologiczne refleksje w obliczu nowego rozumienia języka

Celem tego artykułu jest rewizja takich pojęć jak zdanie, wypowiedź, akt mowy, zdarzenie komunikacyjne $w$ obliczu nowych potrzeb badawczych i szerszego rozumienia jezzyka - języka uwikłanego $w$ złożony proces komunikowania, a zatem jako narzędzia stużacego nie tyle do produkcji znaczen, ile do ich przekazywania i interpersonalnego współtworzenia. Z takiej 
perspektywy język jawi się nie jako system, ale jako jedno z narzędzi symbolizowania znaczeń $i$ intencjonalnych przesłań, które służa do wytwarzania i regulowania więzi społecznych. Zamiarem autorek jest zatem taka redefinicja tradycyjnych dla językoznawstwa i pragmatyki mowy pojęć, aby stały się one dobrym narzędziem dla opisu typu zdarzenia komunikacyjnego $i$ wytworzonej jednostkowej interakcji. Chcemy też usunać istniejące zamieszanie terminologiczne, tzn. wyeliminować używanie tych samych pojęć dla określenia innych zjawisk mownych lub innych poziomów mowy, a w rezultacie zhierarchizować te pojęcia oraz wytyczyć im przejrzyste ramy definicyjne. A wszystko to po to, by w tych ramach dała się zawrzeć także perspektywa odbiorcy jako czynnego uczestnika i wspóttwórcy komunikacyjnego zdarzenia, wypowiedzi, a nawet zdania.

Słowa kluczowe: wypowiedź, zdanie, jednostka mowy, zdarzenie komunikacyjne, zdarzenie mowne, akt mowy

\section{Introduction - definitions of a sentence}

Let us start from the revision of the understanding of the most basic unit of language, from the level of the structure of an utterance, i.e. a sentence. The sentence - considered by everyone an indispensable unit of language - arouses, probably, the highest number of disputes and arguments as to its definition. In the field of traditional linguistics, it has been tackled in over two hundred definitions, among which three groups stand out: structural definitions, structural and semantic definitions, and semantic definitions.

1.1. The first group is constituted by structural definitions. It contains definitions which

a) 'define the sentence as an expression which does not have any external, grammatical relations, that is, as a structurally autonomous unit' (Polański 1999: 669). A drawback of that definition, according to language researchers, lies in the fact that all the 'sentence-utterances' that do have such markers in their grammatical structures remain outside of its scope. While looking at this issue from the perspective of speech itself, it is sentences that have such markers of external reference that are more natural, since a sentence is, in general, a communicative reaction to something. Take, for example, the presence of the contrastive conjunction but in the sentence But in the end he lost. or the presence of a time marker such as then in the sentence And then I started to have doubts.

b) Another structural measure consists in determining the sentence unit through defining its compositional characteristics. "According to some, a sentence is a syntactic, dichotomous structure consisting of the subject and the predicate; according to others - it is a structure whose marker is a finite form of a verb" (Polański 1999: 669-670). Yet, those definitions have their serious limitations as well, which has been emphasised even by their supporters. These are 
generally well-known arguments, but let us recall them briefly. The point is that, if taken literally, these definitions do not comprise avalent sentences (in particular subject-less sentences, e.g. Powiało chtodem. [(It) got chilly - Polish, as a pro-drop language, does not require the subject] or Dnieje. [(It) is dawning]. Nor do they comprise sentences which not only lack the finite form of the verb but also do not allow for it, e.g. Strach pomyśleć. or Widać tak trzeba. [Scary to think. or Apparently the right thing to do. In both cases the dummy subject is not so much unnecessary, but impossible to add].

1.2. The second group consists of mixed, structural and semantic, definitions, with varied distribution of emphasis over the structural or the semantic features. Among these definitions there is one by Zenon Klemensiewicz (1937), widely known in Polish syntax research, according to which "the sentence is a linguistic formation constituting, under specific conditions, a communicative entity and comprising a finite form of the predicate." (Polański 1999: 669-670). In many other definitions of this type, phrases recur, treating the sentence as a linguistic unit of a very specific structure, representing a certain complete thought or having a full sense (Polański 1999: 670). Unfortunately, they do not specify how to understand that complete thought or that full sense and how to interpret the claim concerning those specific conditions under which a given structure constitutes the communicative entity. What is more, it is often hard to reconcile the formal requirements with the postulate of the semantic "completeness", as, on the one hand, sometimes utterances lacking a finite form of the verb, such as, e.g. Warto czasami pomyśleć. [(It is) good to think sometimes.] or Czuć tu gaz. [(It) smells of gas here - the Polish example uses the infinitive $c z u c ́$ ] happen to constitute such small semantically 'complete' units; but, on the other hand, not every predicative form (expressed with a finite form of the verb) constitutes a formally complete thought, e.g. *Pawet is smaller (without expressing the comparison), though it might be an entirely complete utterance.

In turn, according to the semantic definitions, "it is not the formal structure but the meaning that marks a sentence" (Polański 1999: 670). Here, we will consider the communicative completeness of a sentence as the relevant feature of a sentence unit, which means, by the same token, its semantic independence from the linguistic and situational context. That communicative completeness is based on the assumption that the sentence is an expression which is predicating something about an indicated fragment of reality. Thus, it must obligatorily have a thematic-rhematic structure, that is an element indicating what it is predicating about (theme) and an element indicating what is being predicated (rheme). This communicative completeness is understood as follows: a sentence is such an utterance that predicates about the occurrence of something in a complete and finite way. In our opinion, a 
drawback of this definition consists, paradoxically, in its condition of semantic completeness. That is, all the elements of sense, such as: time, place, modality of the event (cf. the discussion of the modality framework below) need to be expressed. That, consequently, results in the fact that only few of our predications on physical and mental reality could be considered as sentences in accordance with that definition. Thus, an utterance: Today beef is surely absent from my fridge. is semantically complete, hence, in accordance with the semantic definition, it fulfils all the conditions of being a sentence, except for maybe one - the communicative and pragmatic one, as hardly anyone will say that. On the other hand, particular natural-linguistic sequences of an utterance, such as, e.g. There is no beef. I've looked in the fridge. There is none for sure. I have just checked. individually do not qualify as sentences, at least not semantically complete ones. Paradoxically, no one speaks in complete sentences and their finished sense is not arbitrarily included in a speaker's mind. It is created, it comes into being in an interaction, as the semantic sense does not reside in the mind of a given individual and does not originate in communicative void, but it is manifested and created in the course of an exchange of thoughts in the face of a communication event.

1.3. Probably the most flexible definition of a sentence, and, at the same time, the most promising one for the study of speech phenomena, has been suggested by representatives of the cognitive orientation of linguistics. It is promising, as it considers as many as three aspects: the syntactic one, the semantic one and the pragmatic one, since cognitivists assume that a sentence construction consists of several layers or levels whose components enter mutual relationships. In other words, they assume that (cf. Tabakowska 2001: 111-143) a sentence:

a. expresses a specific event schema,

b. has a specific syntactic structure,

c. is grounded in a specific pragmatic context. Let

us explain it:

What does it mean that a sentence expresses a specific event schema? It means that sentence is a "grammatical" exponent of a certain ontic and semantic scene of events, the participants of which have been ascribed specific roles and the events - states or actions. Hence, 'event schemas' are carriers of certain ontic predications, expressed in specific semantic orders such as BEING, ACTING, POSSESING, EXPERIENCING, MOVING, etc. Sentence schemas, on the other hand, create construction skeletons for expressing basic event schemas. That is why, cognitivists prefer talking about a schema of a sentence to talking about a sentence.

What does it mean, then, that a sentence has a specific syntactic structure? The schema of a given syntactic structure is usually an exponent of one event schema, while a unit sentence 
with a specific syntactic structure is an exponent of some particular structure and organisation of an event scene, which can be subsumed under a given schema.

Finally, what does it mean that a sentence does not exist outside a specific pragmatic context? In the simplest terms, it means that a sentence never exists and never will in a communication void. Karl Bühler would probably have said that it appears only when it is uttered by a specific sender in a specific time and in a specific space, while pragmatics would add: when it is uttered with a specific purpose. All those components have their formal exponents in the structure of the sentence and justify its ontological existence - cognitivists label them as grounding elements. Thus, grounding justifies and is responsible for the necessity for the immersion of a sentence in the extralinguistic reality, and not only in the spatiotemporal reality, but also in the epistemic one: the reality of the predication, supposition, question, statement, etc.

\section{Grounding mechanisms}

Let us, for a moment, look at the grounding mechanisms themselves and see whether there is any hierarchy among them as well how it indicates the nucleus of the sentence.

According to cognitive linguists, it is the event that is this sentence-forming nucleus. Certainly, neither the event itself nor its perception by the individual can constitute the 'nucleus' of the sentence. But it can and does constitute the 'nucleus' of the process of perceiving something as an event. Such a state of mind expresses its readiness for predicating. And this very state and the desire to verbalise it constitute the sentence-forming nucleus. Consequently, we can see that at the basis of the cognitive understanding of a sentence there is a certain mental readiness of the mind (its 'categorial predisposition') to predicate about events (that is, the readiness for the epistemic processing of ontological phenomena). Hence, a sentence could be said to be a certain semantic predisposition rather than a syntactic one (predisposition to categorise processes and states as well as to translocate, transfer, possess and experience them). This semantic and mental predisposition cannot happen without the participation of a live, present and currently perceiving perception (i.e. an observer, who could be the speaking subject or narrator). That is why, it should not come as a surprise that, according to cognitivists, the imperfective form of the predicate constitutes the nucleus of a sentence, as such predication does not settle the issue of the actual occurrence of the event. When the speaker says: Mary is making a dress, she does not know the results of that action. That is why, the event by itself is not grounded yet. Mary might not have made that dress. The first 
grounding takes place at the sentence level, through predicating about the completion of the action. Then, the speaker predicates that the action has happened, and its effects and results exist. Then she will say: Mary has made a dress. Hence, the dress exists.

The second grounding, the deictic-temporal one, according to cognitivists, consists in the way of expressing relations between the event, happening at the extralinguistic time, and the time of the linguistic message, which is expressed in a grammatical tense. It means that the choice of a given grammatical tense category is, on every occasion, a subjectively understood time line of the speaking subject (that is a moment in which she is speaking). What follows is that the grammatical expression of time, obligatory for a sentence, is determined by placing oneself (that is the speaking subject) within the 'present' time and referring this 'present' to the time of the event that the subject is predicating about. In other words, the deicticity of time references establishes the grammatical order of the sentence. It also means that through the choice of the grammatical tense for predicating about an event, the subject establishes the degree of her temporal proximity from the event being described (an incident, a fact).

The third grounding expresses the attitude of the speaker to the truthfulness of the message expressed by her, that is, it creates the, so called, modality framework. The speaker is either certain that the event being described is a fact or she treats it as hypothetical. An unmarked predication does not have any special markers, but even the slightest hesitation as to its truth needs to be expressed lexically or - let us add - para-linguistically. Cognitivists do not state, however, whether any type of modality should constitute the sentence-grounding nucleus. We believe that it would be sensible to narrow down its semantic field to the alethic modality, which means to the decision on the hypotheticality of an event or its actual materialisation or, finally, lack of it. Why so? Because modalities of the epistemic or deontic type already belong to the cognitive sphere, stipulated by the subject and not to the sphere which is ontically predicated.

The fourth, the most external grounding layer of a sentence, according to cognitivists, expresses its pragmatic functions: whether the postulated state is a statement, question or is it wished for, which is grammatically expressed by means of the mood (the indicative mood, the interrogative mood, the imperative mood). And, yet again, a small disclaimer. Cognitivists identify this sentence-forming level or layer with a speech act, while a speech act has a broader sense and cannot be reduced to grammatically expressed moods. Declarative, expressive acts as well as some commissive acts are not related to particular grammatical moods. In other words, moods are a grammaticalised way of expressing certain pragmatic functions, they are vectors of certain intentions, and these intentions can be categorially ascribed to them, yet 
neither do they exhaust the categories of the intentions of human utterances nor can the use of a given mood always guarantee the intentionality ascribed to it grammatically. Thus, the use of the conditional mood in an utterance such as: Could you explain to me why you always leave your socks under the bed? is not a hypothetical predication, nor even a question, but a grudge or a complaint; and a question of the type: How long can one talk on the phone? is not so much a question about the 'ontology of a phone conversation', but a malicious reproach. Secondly, on the whole, languages have worked out the grammaticality of certain pragmatic functions, but not of all of them. The choice of those functions is determined by anthropology of language and by their pragmatic usefulness. Thirdly, what has been obvious for a long time - the same grammatical mood is used for the realisation of various pragmatic functions (e.g. the conditional mood serves politeness formulas).

For all the above reasons, and also since European linguistics has worked out quite useful notions, such as an utterance and a speech act, we do not find it necessary to identify them with a sentence. On the contrary, it seems by all means methodologically right to consider a sentence as a unit smaller than an utterance and less capacious than a speech act. 'Smaller', though, does not mean less extensive phonologically than an utterance, and 'less capacious' does not mean non-intentional. It only means that a sentence is the smallest unit of utterance, or such a semantic expression of an utterance in which the subject ascertains the 'existence' of some state of affairs, with its grammatical expression in the predicative form. It means, however, that such predicating does not necessarily have the form of a grammatical predicate (though such a form would be the most prototypical).

Summing up, we assume that a prototypical sentence is a verb in the imperfective mood, but semantically a sentence is the mood of alethic predication on the existence of some process and then state. Hence, it can be expressed with other grammatical means, such as an infinitive, e.g. Czuć tu spalenizna. [(It) smells of burning here]. The Polish sentence uses the infinitive form $c z u c$ ]; or by adverbial constructions (with the ellipsis of the finite form of the verb) of the type: Ponuro tu jakoś. [[It is] somehow gloomy here]; Nudne te zajęcia. [Boring (are) these classes] or even by nominal structures of the type: Spokój! [Order!], or courteous questions like: Ciasteczka? [Cookies?] or directives like: Mała czarna! [Short black!]. And, finally, ostensively: through an indicating gesture accompanied by a prepositional construction, like the answer to the question: Where are you going to sit? Here. and indicating the first row of chairs in the lecture hall.

Such an understanding of a sentence is aligned with the cognitive spirit, yet, on the other hand, it strays from it. It is aligned, as we assume as its basis the mental readiness to predicate 
on the existence of a given process, which is most often grammatically (though not always grammatically) expressed through the verb phrase of a specific syntactic schema; it is unaligned - because the modality-grounding layers and pragmatic functions of speech can be perfectly assigned to speech units higher than a sentence, such as an utterance and a speech act, or, finally, a communication event. Because modality and other pragmatic functions may be realised in speech without resorting to the necessity of prior alethic predication.

\section{Definitions of an utterance}

We shall explain that in a moment. Meanwhile, let us trace back the linguistic career of the word utterance.

1. The term wypowiedzenie was introduced into Polish linguistics by Zenon Klemensiewicz (1937) to 'express a closed and syntactically shaped communication unit' (Polański 1999: 645) According to that concept, utterances can be divided into sentences and declarations (oznajmienia). We do not know, however, whether the declarations are a result of a communicative interaction, hence, they do not have to be sentences, or whether the speaker have the communicative freedom of choosing one or the other form still at the level of the system. Therefore, two orders are confused: the order of the units of the linguistic system and the order of the features of communication units, which is methodologically barren. In more recent linguistics, the term utterance is used to indicate a specific sentence uttered by a specific user of the language. In such an understanding, the utterance is conttrasted with the sentence, which is understood more as an abstract unit and falls into the category of language (langue) or to the linguistic competence (in the terminology of generative grammar).

2. In Anglo-Saxon literature and French linguistics the problem of the difference between the sentence and the utterance has been significant and important. For example, Lyons wrote:

We may begin by distinguishing between language-behaviour and the language system which underlies it. When we say that someone is speaking a particular language, English for example, we imply that he is engaged in some kind of behaviour, or activity, in the course of which he produces vocal signals of greater or less duration, as well as various - let us underline it - nonvocal signals which interact with, and may determine the interpretation of, these vocal signals. The vocal signals we will call utterances. Now the term 'utterance' (unlike, for example, the French énonciation and énoncé) is ambiguous in that it may refer to a piece of behaviour (an act of uttering: French énonciation ') as well as to the vocal signal which is a product of that behaviour (French énoncé). These two sentences may be distinguished, when this is necessary, by means 
of the term utterance-act and utterance-signal. Philosophers are perhaps more accustomed to using the term utterance in the sense of an act (or activity), linguists [more] in the sense of a signal, though according to explicit definitions by Bloomfield (1926) and Harris (1951), it could be construed as denoting both.

(Lyons 1977: 26)

[According to Harris] an utterance is any stretch of talk, by one person, before and after which there is silence on the part of that person [....] It follows from the definition [according to Lyons] that an utterance may be of any length: it may consist of a single word, a single phrase or a single sentence $[\ldots]$, it may consist of a sequence of sentences; it may also consist of one or more grammatically incomplete sentence-fragments; and it may have one sentence (or sentencefragment) parenthetically included within another. In short, there is no simple relation of correspondence between utterances and sentences. Both the speaker's behaviour and the utterances he produces are observable and, up to a certain point, can be described in purely physical or external terms. [In other words, t] he terms 'language-behaviour' and 'utterance' [...] belong to the pre-theoretical or observational vocabulary of the linguist.

(Lyons 1977: 26-27)

Let us note that, in a way, Lyons, and, to be exact, Bloomfield and Harris, as it is on their positions that Lyons bases his views, is precursory, and to some extent - epigonic. Precursory - when he notes that language behaviour may be accompanied by non-verbal signals, sometimes deciding on the interpretation of the meaning of the utterance itself (cf. Lyons 1977: 27). It means that Lyons was aware of the role that non-verbal and paralinguistic means play in the process of communication. Today, we can even hear voices that a pragmalinguistic model based on the speech act without consideration for nonverbal behaviours is a methodological mistake. Lyons, or actually Harris, was also precursory when he claimed that an utterance is any stretch of talk, by one person, before and after which there is silence on the part of that person, and also when Lyons wrote that "utterances are unique physical events; as such they can be referred to in terms of observational metalanguage of linguists" (Lyons 1977: 28). He was epigonic while claiming that "the linguist (...) is not generally concerned with utterances as unique observational entities. He is interested in types, not tokens". And later, when he wrote: "When we say that two utterances are tokens of the same type, we are implying that they have some structural or factual identity by virtue of which native speakers will recognize their sameness. (...) It is now generally agreed by linguists that two utterance-tokens might differ grossly acoustically and yet count as structurally identical for the native speaker" (Lyons 
1977: 28). And again he was precursory when he doubted the real possibility of such functional identity of two utterances. As he wrote: "Nor does it seem possible to identify utterances as tokens of the same type, as far as the vast majority of utterances are concerned at least, in terms of their functional identity as responses to the same stimuli (when the stimuli themselves have been independently and appropriately grouped together as tokens of a particular type)" (Lyons 1977: 28-29). Current linguists, or at least speech pragmatists, communicativists and nonverbal behaviour researchers agree, just contrary to what Lyons wrote, that two utterances, if differing in anything, are a display of different communication needs and different intentional messages. What is more, the current attitude to the phenomena of speech and language goes towards observing language behaviours of humans rather than studying the language; searching for the unit of speech rather than the unit of language. Hence, a radical supporter of the concept of communicativism and a scientific approach to the study of language phenomena, Yngve, postulated in his theses from 1992:

Instead of studying language, we study how people communicate, both verbally and nonverbally. (...) Instead of developing grammatical theories of language we develop scientific theories of people from a communicative point of view. [...] Instead of searching for the grammatical properties of language, we search for the communicative properties of people. Instead of seeing people as using language or as speaking words or sentences, we see them as carrying out communicative tasks. Instead of seeing a person as a language user, we represent a person as a communicating individual, a concept that owes nothing to the grammatical tradition. (...) Instead of contested definitions of language, we see observable behavior as communicative if it affects subsequent observable communicative or noncommunicative behavior of the same person or others. (...) Instead of speaking of meaning being conveyed by language, we see communicative behavior as causing changes in the linguistic and nonlinguistic properties of people. [And, finally] Instead of saying that utterances are partly alike and partly different, and no two utterances are exactly alike phonetically, we talk about observable communicative similarities and differences of people, and observe that no two people are exactly alike communicatively.

(Yngve 1992: 515-516)

It is symptomatic that similar tendencies, that is departing from the typological type of studies (classification of nonverbal signs) towards observations of particular nonverbal behaviours in a particular interaction and the whole of a communication event, can be also noticed in the field of studies on nonverbal communication. Mark Knapp and Judith Hall describe the evolving trends in the studies on nonverbal communication as follows: 
from studying noninteractive situations to studying interactive ones, from studying one person to studying both interactants, (...) from single-meaning and single-intent perspectives to acknowledging that often multiple meanings occur and multiple goals exist, from a measurement perspective focused almost exclusively on frequency and duration to one that also includes issues related to when and how a behavior occurs, from attempting to control context by eliminating important and influential elements to attempting to account for such effects, [... and finally] from studying only culture or only biology as possible explanations of behavior to examining the roles both play.

(Knapp, Hall 2013: 24)

Summing up, it would be nice to preserve some unit of the system and it is hard to think that it is not there, but, to be honest, in an actual linguistic reality even such a unit as a sentence does not exist without grounding. Thus, it is easier to define units of speech than speak about units of the system. Let the utterance remain real, physical speech, and the sentence - one of its expressions: alethic predication. Because that immediately explains why sometimes it happens that in a speech event we make a sentence, and sometimes we do not. When, for example, I am opting for a different reality than my interlocutors, I can reply to a sentential directive of the type: Sit, please., establishing a new viewpoint of events and saying, e.g. No, I will stand. However, if I accept that viewpoint, I can only say Thanks and sit down. Similarly, when I ask: Are you listening to me?, my receiver may just mutter: Mhm, or Yeah or even just nod, while if he opts for a different scene of events, he will predicate something of the type: Can'tyou see I'm washing up? That explains the obvious difference between a sentence and an utterance, underlined by speech researchers, namely, that "the utterances of everyday conversation tend to be, in some sense, grammatically incomplete or elliptical" (Lyons 1977: 29). As a matter of fact, their grammatical incompleteness (if someone insists on keeping this phrase) is well justified by communication competence. Speaking, and thus also communication, competence probably also includes the right choice of linguistic means to express a specific intention or to obtain the intended pragmatic goals, i.e. to perform the proper speech act. Let us, then, have a quick look at the linguistic history of this term and wonder whether there is any difference between an utterance and a speech act.

\section{Definitions of a speech act}

Ferdinand de Saussure spoke about components of an individual speech act, appreciating the roles of the sender and the receiver, yet, he understood a speech act as, actually, any language- 
phonic transmission of an acoustic image from the mouth and the brain of the speaker to the ears and the brain of the listener. But the transmission of the 'senses' does not mean yet pragmatic intentionality and a communication goal of sending a given acoustic image.

Karl Bühler (1934) placed a speech act at a slightly higher level of abstraction. He did consider it as a specific expression of single individual speech, yet, he ascribed to it a higher level of formality and, what follows, an expression of language awareness rather than of language action (cf. Polański 1999: 27). In other words, Bühler claimed that language action is of subjective and not very formalised character. It is more of an expression of thoughts and emotions than their conscious display. Only a 'speech act', in his opinion, is a conscious communication action - the speaker makes a choice of the linguistic form or formula which, in her opinion, expresses specific speech needs.

One could think, then, that Bühler's distinction between a language action and a speech act is a distinction concerning the level of awareness and linguistic competences. But it does not seem to be just that. While thinking about the degrees of formalisation and subjectivisation of language formations, Bühler indicated that both the sender and the receiver were aware of participating in the process of communication. Therefore, the care for the right representation of the mental contents of the sender and the right choice of symbolic means as well as the awareness of what reactions they may evoke in the receiver constitute the grounds for considering a given language action as a speech act. To put it in simpler words, one could say that every speech expression is a language action, yet, not necessarily a speech act. For example, when we are expressing our indignation with the persistent and importunate exclamation (using e.g. the most popular Polish vulgar word), we do not necessarily show our care for the receiver and even less so for the right representation of our contents which evoke this indignation. It seems to us that only an attempt at linguistically objectifying and symbolising would mean, according to Bühler, the performance of a speech act, that is, a conscious description of mental and emotional experiences for specific symbolic contents. It is clear that Bühler felt very strongly about the difference between a manifestation of speech and a conscious language action. It is only the latter that he would consider a speech act. However, from the point of view of speech pragmatics alone, it is hard to set strict boundaries between a conscious and an unconscious speech action, let alone set strict boundaries for its formalisation.

The same formula or even pure expression may be fortunate or not, intentionally conscious or not in another communication event. It is hard to predicate about the degree of its formalisation, since a convention may be often formalised, yet not necessarily more complex 
abstractly. Thus, maybe it would be a better way of handling Bühler's dichotomy if we did not speak about the linguistic awareness, but about the awareness of linguistic usage, that is, about the communication level. Then, every language action, every utterance would be a speech act, though not necessarily a fortunate, rhetorically appropriate and communicatively competent one.

American descriptivists also considered a speech act equal to an utterance, though they interpreted it in the behaviourist categories of stimulus and reaction. The way Leonard Bloomfield saw it is as follows: 'an utterance is a reaction to some stimulus, which can have either a nonverbal or verbal character. The utterance of the speaker is a linguistic stimulus for the listener who can react to it either with some activity (for example by complying with the request or the order of the speaker) or with his/her own utterance, that is, linguistically' (Polański 1999: 28). Such a perception broadens the understanding of the speech act, adding both a nonverbal reaction and complex (verbal and nonverbal) reactions. It does not contribute anything, however, when it comes to linguistic and communication competences. A speech act is a free and voluntary reaction to the world and events in it. So the borderline between reactions of the communicative type and reactions to operant stimuli becomes blurry. Meanwhile, a sender will react to a spoonful of very hot soup differently when she is alone, and differently when she is in company. Only the latter releases in her a reaction of the communicative type. In that situation she will hold back the natural reaction of spitting the soup out, excusing the wince with a smile and uttering some white lie: Tasty, though maybe a bit too hot. Sorry.

Ch.C.Fries even tried to base the classification of utterances on the criterium of the type of response they evoke. He distinguished 3 main types of utterances:

1. those that are followed by "oral" responses (that is, e.g. questions);

2. those that are followed by "action" responses (that is, e.g. requests and orders);

3. those that are accompanied by very brief oral signals (such as yes, $m m$-hmm, aha) indicating attention on the part of the listener (cf. Polański 1999: 28).

Fries was surely precursory, as he was probably the first one to sense that a reaction to a linguistic action is a significant component of a communication event and, in a way, a verifier of verbal messages (the intention of the speech act or the utterance). But, as visible again in those attempts at classifying, the levels of communicative reactions are unfortunately mixed up with performance actions (e.g. the performance of the request in response to the request is mixed up with the verbal signals maintaining the communication bond).

Performance action would be a perfect test both for the causative power of speech acts and for 
the verification of their intentional premises, but only if the question was also answered and if the reaction to a request was always an extralinguistic action. Yet, an utterance of a similar type (formally) may be followed by various reactions: non-linguistic action, verbal retort or a complex (verbal and nonverbal) reaction.

One aspect of Fries' argument seems right: noticing the importance of the receiver's reaction as a significant element which verifies the appropriateness of the use of a specific speech act and the fact that only his reaction can constitute such a verifier. The receiver may, when asked to make tea, e.g. go and make it, which indicates the appropriate use of the requesting formula. He can also respond with indignation and only nonverbally, showing what an inappropriate request that was. But the reaction (verbal or nonverbal) will always be a verifier of the communication competences, and not the linguistic competences - of the speech competences, and not of the systemic ones.

Austin used the term speech act as a category broader than the utterance, since a speech act can be just as well a sentence, one word or even a gesture. As Lyons (1989: 325) points out, Austin uses the term speech act rarely, and though he uses all three of its levels: locution, illocution and perlocution while defining it, the methods and tests for setting boundaries among them that he suggests tend to fail, which, in consequence, does not allow for a strict division of illocution from perlocution and locution. One thing is certain, though Austin, just like Searle, his follower, puts the illocutionary aspect of an utterance in the centre. According to Lyons (1989: 325), the term speech act itself is quite unfortunate and potentially misleading. First of all, because it does not refer to the act of speaking, that is creating an oral utterance itself, but to something more abstract, i.e. to a type or category of specific language action such as a commissive, condolences, apology, etc. On the other hand, however, he wants to understand it as an actual language action, because he notes that speech acts can be accompanied by or even replaced with specific nonverbal behaviours. For example, you can beckon someone with a conventionalised hand gesture replacing a verbal utterance this way. Hence, the conceptual apparatus created by Austin allowed, to his mind, for describing conventionalised acts of nonverbal behaviour, which is confirmed by current studies. That important aspect of Austin's understanding of the category of speech act either eluded other researchers or, as in the case of Searle, it was rejected. What has, however, remained as the most essential component defining a speech act is its intentionality.

Cognitivists introduce a generalised concept of communicative intent to cover all goals that we want to achieve with the use of language, such as informing, asking, ordering, persuading, encouraging, etc. As pragmatics deals with acting with the use of language, it 
should establish and specify the main types of these actions.

On this approach, speech acts are categories of linguistic actions. Those, in turn, are defined by communicative intent, i.e. by their pragmatically intended goal. Hence, a linguistic action is identified with the category of speech act, which seems methodologically wrong, as a language action is not, after all, a category of speech act, but an actual act. It can be ascribed to a specific category of speech act and to a specific type of linguistic action, yet, that does not change the fact that a specific act is neither a type, nor a category.

This terminological mess results from the fact that the term speech act is used in topic literature in two different meanings. One - in the understanding which we use for the term utterance, i.e. a specific speech behaviour of a specific sender in a specific situation; the other one - when we use this term for defining the intentionality of the utterance, i.e. what was the purpose of it.

It is probably so, because in pragmalinguistics the speech act was identified with illocution for too long. Austin and Searle did it, and so did others, attached too much to the status of linguistic forms as creating specific intentionalities, in the sense of speakers having at their disposal a specific repertoire of linguistic tools. The attempt at searching for these tools to express specific intentions (e.g. promising) led to the situation in which the speech act itself (already in the illocutionary meaning) was and still is mistaken for the category of that act.

Meanwhile, as the analysis of the views of linguists themselves shows, the speech act understood as a specific speech behaviour does not actually differ much from what in the field of linguistics was considered to be an utterance. 'Actually', as a deeper insight into those views allows us to draw the conclusion that after all the researchers felt the subtle differences between the levels of speech and communication competences, though, of course, they did not name them that way. They were also very far from denying the view that allowed them to identify language units and not speech units. We, however, are going to move further: maybe we need to think the opposite way? Maybe speech units are actually only units of the system? Therefore, maybe searching for them should be enough to understand language, speech and communication abilities of people who express themselves and act by means of a given language? Because, when we realise that those competences comprise: cognitive skills to make alethic, epistemic and modal judgements; the skills to choose the linguistic means most appropriate in a given situation; as well as the rhetoric ability to judge when and to whom we are talking, we will understand that all these competences imply, firstly, the ability to utter sentences; secondly, the ability to transform them into linguistic utterances; and, finally, to express and convey specific intents or perform them as particular speech acts. 


\section{Utterance and speech act compared}

Thus, what is an utterance and how does it differ from a speech act? Sometimes it does not, sometimes it does. The utterance is every verbal action of one of the participants of a specific communication event, aimed at expressing a specific pragmatic intent, which means performing a specific speech act. What that act is, though, is decided on by the pragmatic conditions of that utterance, and thus also by the extralinguistic - paralinguistic and nonverbal - factors which accompany that act or, actually, constitute its intentionality. For example, if the propositional content of an utterance includes 'coming somewhere again' in the shape of the utterance I'll come here again, then whether an apparent promise becomes an actual threat is decided on by the change of the paralinguistic effects (e.g. the intonation or the tempo of the utterance) and the introduction of nonverbal elements, such as finger wagging or frowning. Similarly, let us acknowledge that a linguistic action like aha or $\mathrm{mmhmm}$ is an outright utterance of one of the participants of a communication event, the purpose of which is to maintain the interactive bond, and in the 'predicational' way - it is an act of consent to what the other participant of the interaction is saying. But the type of consent is again decided upon by paralinguistic and nonverbal effects. Aha may be a quick or hasty confirmation and an onset of a new intent Let me also say something., especially when it is accompanied by a quick repetition and a quick head and hand movement quietening the interlocutor. But it can be an expression of a completely different act - of a deeper, more truthful and more reflexive confirmation (when that aha is intoned slowly and at a lower pitch). And again, the same words: That's it. Full stop! may be an expression of intentional instruction of the type: Now put a full stop; but they can also be an expression of impatience and a directive appeal to the partner to stop the course of reasoning (especially if this utterance is accompanied by a cutting hand gesture), etc.

\section{Conclusion}

This whole disquisition was needed so that we could formulate the simple conclusions. First of all, the necessity to differentiate between the speech and communication competences. Second of all, the reinstating of the real, processual character of the static concept of utterance, and, consequently, the introduction of the receiver into the scene of a communication event - the receiver who, through his verbal or nonverbal actions, may ultimately be a verifier of the

actually sent intents included in the message sent to him. While thinking about the non-felicity of the speech act, Austin spoke of its abuse or inappropriateness. Yet, he always blamed that 
abuse or misfire on the insincerity or incompetence of the sender. However, this inappropriateness does not have to result from the linguistic incompetence or from the inappropriate choice of communication means. Instead, it can consist in an inability to cooperate communicatively, i.e. to predict the perlocutionary effects by considering the specific receiver at the specific scene of the communication event. The thing is that, from the methodological point of view, when we are examining the real effects of speech acts, we cannot a priori predict all the real effects of their impact. Their predicting is particularly impossible when the linguistic utterance remains beyond the scope of a specific communication event, specific nonverbal and paralinguistic behaviour. Because the receiver interprets our utterance based on the whole communication event, and not based on the utterance itself only. And that is why he should be a verifier of the real intentional messages, both the predicted and the unpredicted ones, as the latter, seemingly unpredicted, may be conveyed beyond the conscious intentionality. And once conveyed, they are mentally registered and reacted to, verbally or nonverbally. Hence, studying speech as a communication phenomenon must consider a real receiver at the stage of events because only his presence allows the linguist to genuinely discover the real messages included in specific linguistic actions (utterances), immersed in specific communication behaviours, as language did not happen to stumble over communication one day, but was born in it.

Thus, the new research perspective is to return to the study of the process of speech and communication behaviours, and from that perspective only try to determine units of speech and, maybe then, postulate the existence of any units of language. Due to that, and due to all of the above, we have allowed ourselves the freedom to reverse the order of speech units and consider as the basic level of its appearance not the systemic sentence or utterance, not even the speech act, but the communication event in which this unit (that is the sentence or the utterance) finds the semantic reason for its existence. Because even the simplest sentence does not appear in the communication void. Therefore, in order to facilitate the conclusions resulting from our revision of traditional linguistic terms, we shall now present our own understanding of them, in the form of short definitions:

COMMUNICATION EVENT - a communication situation comprising at least two speech acts in an interactive space between the sender and the receiver, in which real communicative action of both parties (verbal, nonverbal or mixed) takes place.

SPEECHEVENT - a specific utterance, constructed by the speaker in a specific place and time for a specific reason or as a reaction to another speech event. 
SPEECH ACT - a unit from the communication competence level - any real linguistic or conventionally non-linguistic action (communicatively ritual for a given culture) with a specific and predicted pragmatic goal or intended / unintended perlocutionary effects.

SPEECH ACT CATEGORY - a unit from the metalinguistic level - a repertoire of all linguistic and culturally conventional (prototypical) means and ways of realising specific intents.

UTTERANCE - a unit of speech competence - any real linguistic action resulting from thought, expression, emotions and pragmatic needs, performed within the framework of speech and silence of an individual.

SENTENCE - a unit of (systemic) linguistic competence - an alethic predication on the existence of a process, event or state of things, semantically, prototypically expressed with a predicative statement and deictically (spatiotemporally) grounded.

\section{Acknowledgements}

This article was published for the first time in Polish in 2006, in Kognitywizm and komunikatywizm - dwa bieguny wspótczesnego językoznawstwa, edited by Władysław Chłopicki, Język a komunikacja 9. Kraków: Tertium: 41-57.

Translation into English: Teresa Przyprawa

\section{References}

Austin, John L. ([1961] 1993) “The Meaning of the Word” [In:] Philosophical Papers. Oxford: Oxford University Press; 23-43.

Bloomfield, Leonard (1926) “A Set of Postulates for the Science of Language.” Language $2(3) ; 153-164$.

Bühler, Karl ([1934] 1990) Theory of Language. [Sprachtheorie. Die Darstellungsfunktion der Sprache. Jena: G. Fisher]. Trans. Donald Fraser Goodwin. Amsterdam/Philadelphia: John Benjamins.

Fries, Charles Carpenter (1952) The Structure of English. An Introduction to the Structure of an English Sentence. New York: Harcourt, Brace and World.

Harris, Zeelig (1951) Methods in Structural Linguistics. Chicago: University of Chicago Press. 
Klemensiewicz, Zenon (1937) Składnia opisowa współczesnej polszczyzny kulturalnej, Kraków: Polska Akademia Umiejętności.

Knapp, Mark L., Judith A. Hall (2013) Nonverbal Communication in Human Interaction. Boston: Wadsworth Cengage Learning.

Lyons, John (1977) Semantics. Cambridge: Cambridge University Press.

Polański, Kazimierz (ed.) (1999) Encyklopedia językoznawstwa ogólnego. Wrocław: Zakład Narodowy im. Ossolińskich.

Searle, John (1969) Speech Acts. Cambridge: Cambridge University Press.

Tabakowska, Elżbieta (ed.) (2001) Kognitywne podstawy języka i językoznawstwa. Kraków: Universitas.

Yngve, Victor H. (1992) "Why is Language Different?” [In:] Ruth M. Brend (ed.) The Eighteenth Lacus Forum 1991. Lake Bluff: Linguistic Association of Canada and the United States; 511-518. 